\title{
HEAVY METAL CONTAMINATION IN THE SURFACE SEDIMENTS OF XUWEI-LIEZIKOU OFFSHORE AREA, NORTHERN JIANGSU PROVINCE, CHINA
}

\author{
MENG, K. ${ }^{1,2}-\mathrm{XU}, \mathrm{M}^{1,3^{*}}-\mathrm{LI}, \mathrm{F}^{3^{*}}-\mathrm{TU}, \mathrm{C}^{1}-\mathrm{DING}, \mathrm{Y}^{4}$ \\ ${ }^{1}$ College of Geography, Nanjing Normal University, Nanjing 210023, China \\ (phone:+086-025-85898551; fax: +086-025-85898551) \\ ${ }^{2}$ Jiangsu Yunfan Testing Technology Co., Ltd., Nanjing 210023, China \\ ${ }^{3}$ College of Marine Science and Engineering, Nanjing Normal University \\ Nanjing 210023, China \\ ${ }^{4}$ Nantong Marine Environmental Monitoring Center, Nantong 226005, China \\ *Corresponding authors \\ e-mail:xumin0895@njnu.edu.cn; lifei086@sina.com
}

(Received $31^{\text {st }}$ Oct 2018; accepted $28^{\text {th }}$ Jan 2019)

\begin{abstract}
A total of 30 samples were collected from surface sediments of Xuwei-Liezikou offshore area, northern Jiangsu Province, China, and the concentrations of 7 heavy metals including $\mathrm{As}, \mathrm{Hg}, \mathrm{Cu}, \mathrm{Pb}, \mathrm{Zn}$, $\mathrm{Cr}$ and $\mathrm{Cd}$ and their spatial distributions were determined. Geo-accumulation index $\left(I_{g e o}\right)$, pollution load index $(P L I)$ and potential ecological risk index were applied to evaluate the pollution status. The mean concentrations of $\mathrm{Cd}, \mathrm{Pb}, \mathrm{As}, \mathrm{Zn}, \mathrm{Cu}$ and $\mathrm{Hg}$ were 2.62, 1.96, 1.70, 1.42, 1.32 and 1.30 times of their respective background values, which indicated there were obvious accumulations of these heavy metals in surface sediments. It was observed that the high heavy metal concentrations were in the western and northern regions of the study area except for $\mathrm{Cu}$, mainly located in estuary and port regions. The sediments in the entire study area were moderately polluted, and the main pollution factors were $\mathrm{Cd}$ and $\mathrm{Pb}$. The study area suffered from a level between low and moderate ecological risks, and $\mathrm{Cd}$ was at the considerable ecological risk level, $\mathrm{Hg}$ was a moderate ecological risk, while other metals had low ecological risk level.
\end{abstract}

Keywords: heavy metal concentration, spatial distribution, contamination assessment, ecological risk, northern Jiangsu Province

\section{Introduction}

The heavy metal pollution in marine environment has received much attention, becoming a global environmental issue, because of their toxicity, wide sources, persistence, ecological risk, and the non-biodegradable nature of the contamination (Irabien and Velasco, 1999; Burger and Gochfeld, 2003; Hu et al., 2011; Waheed et al., 2013; Bastami et al., 2015; Harikrishnan et al., 2017). As we all know, sediments contain and accumulate a large number of heavy metal elements (Gao et al., 2015; Fang et al., 2016; Zhang et al., 2017). The sediments are not only a 'sink' of heavy metals but also a 'source' (Matthiessen and Law, 2002; Hill et al., 2013; Machado et al., 2016; Chen et al., 2017). On the one hand, heavy metal elements enter the water through various ways, these elements enter the water where they are subsequently adsorbed by suspended substances and settle on the sea floor. On the other hand, when some physical and chemical properties of the water change, the heavy metal elements in sediments would be released and thereafter cause pollution to the water. Therefore, the 
analysis of heavy metals in sediments is necessary to our understanding and protection of the marine environment.

Xuwei-Liezikou offshore area is located in the southern part of Lianyungang city in the northern Jiangsu Province of China and is an important part of Lianyungang Port. Because of its superior geographical position, excellent port resources and rich fishery resources, the study area has become a major gathering place for mariculture, port development and coastal industry. The development of ports and a large number of land-based pollutants entering the sea are bound to exert great pressure on the marine environment (Nethaji et al., 2017; Jahan and Strezov, 2018). The evaluations of heavy metal in sediments form Lianyungang offshore area have been investigated (Zhang et al., 2013; Li and Li, 2016; Zhang et al., 2016). However, previous studies mainly focused on the study of heavy metals in columnar sediments form the northern Lianyungang offshore area (e.g. Haizhou bay), and few reports have evaluated heavy metal contents and pollution in surface sediments form the southern Lianyungang offshore area. Therefore, this study evaluates the concentration and pollution level of heavy metals (As, $\mathrm{Hg}, \mathrm{Cu}, \mathrm{Pb}, \mathrm{Zn}, \mathrm{Cd}$ and $\mathrm{Cr}$ ) in surface sediments of Xuwei-Liezikou offshore area in northern Jiangsu Province, which is a supplement to the study on heavy metals of Jiangsu Province and provides reference data for controlling heavy metal pollution in the marine environment.

\section{Materials and methods}

\section{Study area}

Xuwei-Liezikou offshore area is located in the south wing of Lianyungang Port in Jiangsu Province of China, bordered by the Yellow Sea in the east, the Yangtze River Delta Economic Belt in the south, and the Bohai Economic Circle in the north. Its estuaries include the Xishu River estuary on the west side of the Dongxi Island, the Shaoxiang River estuary and Xiaowa Port on the nearshore of the Xuwei Port, and the Liezikou estuary and Guanhe River estuary in the southwest. The coastwise areas of the study sea area belong to a coastal plain. The coast stretching from the Xishu River estuary to Shaoxiang River estuary is a bedrock coast with a coastline of $40.25 \mathrm{~km}$. The coast stretching from the Shaoxiang River estuary to the Liezikou estuary is an erosive muddy coast with a coastline of $32.06 \mathrm{~km}$. The coast stretching from the Liezikou estuary to the Guanhe River estuary is an erosive silty muddy coast with a coastline of $39.08 \mathrm{~km}$.

There are also two sea-discharging projects in the study area, including the Lingang Sewage Treatment Plant treating the sewage from the Harbor Industrial Park in the Guanyun County and the Lianyungang Zhongxin Sewage Treatment Plant treating the sewage from Lianyungang Chemical Industrial Park. The sewage source involves industries about electricity, metallurgy, chemical, shipbuilding, paper making, pesticides, and pharmaceuticals.

\section{Sample collection and processing}

In the tide period of October 2014, a survey of the marine environment was carried out in Xuwei-Liezikou offshore area, northern Jiangsu Province, China. A total of 30 surface sediment survey stations were deployed. The coordinates and details of the sampling location points are listed in Table 1 and shown in Fig. 1. Sample 1, Sample 2, 
and Sample 4 are located on the northeast side of Dongxi Island. Sample 3 is on the north side of the west embankment. Sample 8, Sample 11 and Sample 12 are on the northeast side of the Guanhe River estuary, and Sample 13 is on the Guanhe River estuary. Others survey samples are concentrated in the inner areas of the Xuwei Port. The survey investigated items including arsenic (As), mercury $(\mathrm{Hg})$, copper $(\mathrm{Cu})$, lead $(\mathrm{Pb})$, zinc $(\mathrm{Zn})$, chromium $(\mathrm{Cr})$ and cadmium $(\mathrm{Cd})$.

Table 1. Coordinates of sampling locations

\begin{tabular}{|c|c|c|c|c|c|}
\hline Sample & Coordinates & Sample & Coordinates & Sample & Coordinates \\
\hline 1 & $35^{\circ} 04^{\prime} 16.70^{\prime \prime} \mathrm{N} 119^{\circ} 40^{\prime} 07.14^{\prime \prime} \mathrm{E}$ & 11 & $34^{\circ} 42^{\prime} 36.87^{\prime \prime N} 120^{\circ} 13^{\prime} 39.87^{\prime \prime E}$ & 21 & $34^{\circ} 33^{\prime} 19.85^{\prime \prime N} 119^{\circ} 39^{\prime} 41.19^{\prime \prime}$ \\
\hline 2 & $34^{\circ} 57^{\prime} 18.28^{\prime \prime} \mathrm{N}$ & 12 & $34^{\circ} 37^{\prime} 15.93^{\prime \prime} \mathrm{P}$ & & $34^{\circ} 31^{\prime} 40.03^{\prime \prime}$ \\
\hline 3 & $34^{\circ} 46^{\prime} 50.34^{\prime \prime} \mathrm{N} 1$ & 13 & $34^{\circ} 27^{\prime} 29.01^{\prime \prime} \mathrm{N}$ & 23 & $34^{\circ} 32^{\prime} 19.82^{\prime \prime}$ \\
\hline 4 & $34^{\circ} 59^{\prime} 15.86 " \mathrm{~N}$ & 14 & $34^{\circ} 44^{\prime} 46.27^{\prime \prime} \mathrm{N}$ & 24 & $34^{\circ} 40^{\prime} 40.11^{\prime \prime} \mathrm{\perp}$ \\
\hline 5 & $34^{\circ} 42^{\prime} 42.91 " \mathrm{~N}$ & 15 & $34^{\circ} 41^{\prime} 24.37^{\prime \prime} \mathrm{N}$ & 25 & $34^{\circ} 36^{\prime} 43.98^{\prime \prime} \curvearrowright$ \\
\hline 6 & & 16 & $9^{\circ} 36^{\prime} 33.05^{\prime \prime} \mathrm{E}$ & 26 & $34^{\circ} 37^{\prime} 57.96^{\prime \prime} \mathrm{N}$ \\
\hline 7 & $34^{\circ} 36^{\prime} 13.98^{\prime \prime N} 119^{\circ} 35^{\prime} 43.84^{\prime \prime E}$ & 17 & $34^{\circ} 43^{\prime} 02.51^{\prime \prime N} 119^{\circ} 38^{\prime} 29.32^{\prime \prime E}$ & 27 & $34^{\circ} 39^{\prime} 26.66^{\prime \prime N} 119^{\circ} 34^{\prime} 45.00^{\prime \prime} \mathrm{E}$ \\
\hline 8 & $34^{\circ} 51^{\prime} 06.62^{\prime \prime} \mathrm{N} 120^{\circ} 01^{\prime} 06.66^{\prime \prime} \mathrm{E}$ & 18 & $34^{\circ} 35^{\prime} 34.23^{\prime \prime N} 119^{\circ} 36^{\prime} 44.66^{\prime \prime} \mathrm{E}$ & 28 & $34^{\circ} 37^{\prime} 41.43^{\prime \prime N} 119^{\circ} 35^{\prime} 58.95^{\prime \prime} \mathrm{E}$ \\
\hline 9 & $34^{\circ} 37^{\prime} 48.48^{\prime \prime N} 119^{\circ} 48^{\prime} 43.39^{\prime \prime} \mathrm{E}$ & 19 & $34^{\circ} 39^{\prime} 57.74^{\prime \prime} \mathrm{N} 119^{\circ} 44^{\prime} 50.55^{\prime \prime} \mathrm{E}$ & 29 & $34^{\circ} 37^{\prime} 15.01^{\prime \prime N} 119^{\circ} 37^{\prime} 15.46^{\prime \prime E}$ \\
\hline 10 & $34^{\circ} 34^{\prime} 40.69^{\prime \prime} \mathrm{N} 119^{\circ} 44^{\prime} 59.25^{\prime \prime} \mathrm{E}$ & 20 & $34^{\circ} 37^{\prime} 13.56^{\prime \prime} \mathrm{N} 119^{\circ} 41^{\prime} 07.21^{\prime \prime} \mathrm{E}$ & 30 & $34^{\circ} 38^{\prime} 51.00^{\prime \prime N} 119^{\circ} 31^{\prime} 32.21^{\prime \prime E}$ \\
\hline
\end{tabular}

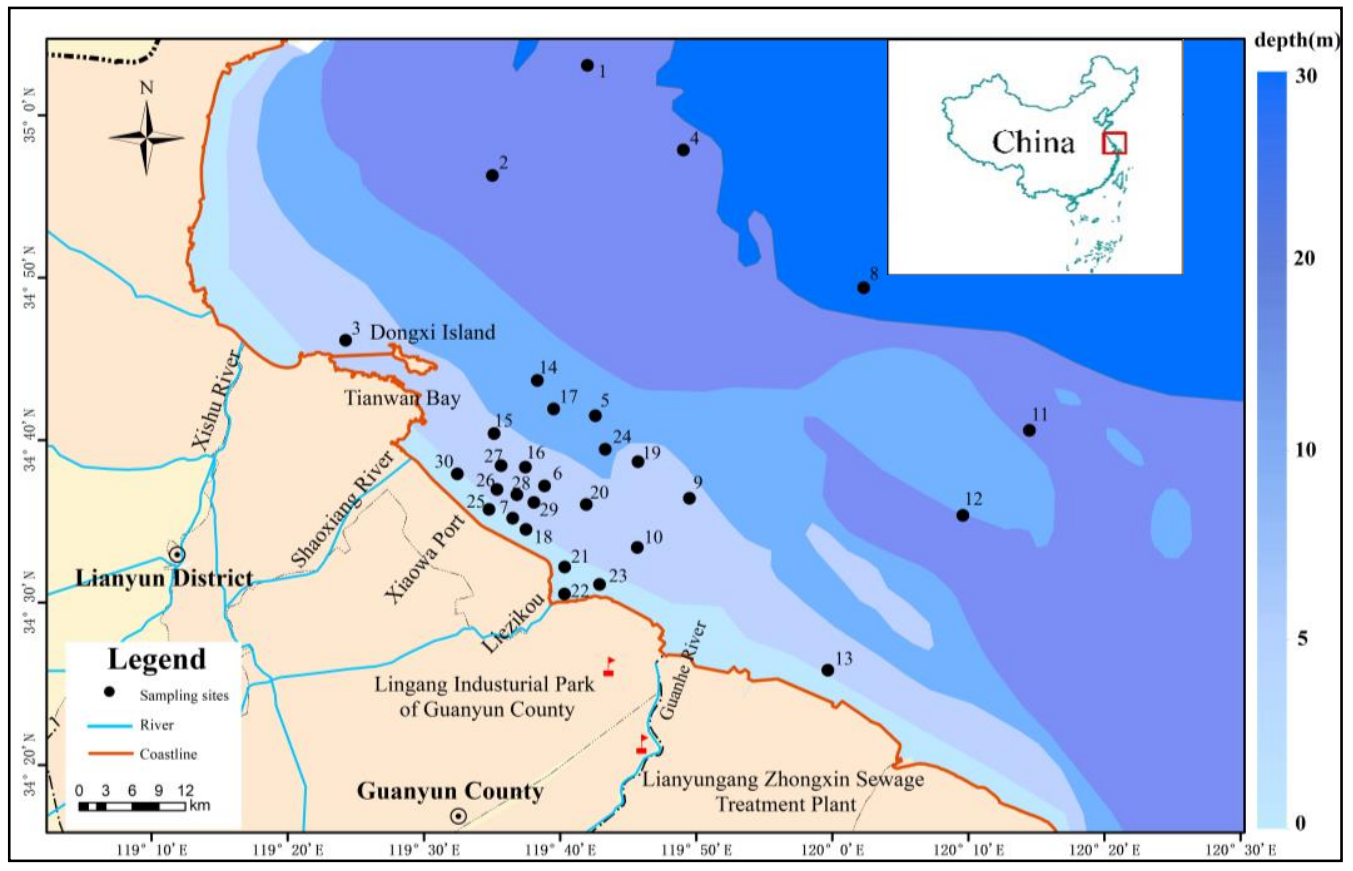

Figure 1. Locations of surface sediment sampling sites in Xuwei-Liezikou offshore area

The collection of sediment samples was carried out on October 10th, 2014. The methods used for the sample collection on site, the pretreatment and the preservation were in strict accordance with the Marine Monitoring Regulations of China (GB17378.4-2007) (AQSIQ, 2007). Samples that could not be analyzed on site were stored in a dark place after steps concerning subpackage, pre-treatments, freeze or sealing with the added fixing agent, and wrapping with plastic bags. Samples that need to be investigated were transported to the laboratory by the responsible person after the field sampling. Sediment samples were analyzed and tested at Nantong Marine 
Environmental Monitoring Center. The concentrations of $\mathrm{Cu}, \mathrm{Zn}, \mathrm{Pb}, \mathrm{Cd}$ and $\mathrm{Cr}$ were determined by atomic absorption spectrometer (Varian AA240FS), and for As and $\mathrm{Hg}$ were measured by atomic fluorescence spectrometry (Beijing Jitian Instrument Co. AFS-930).

\section{Evaluation method}

\section{Statistical evaluation}

The standard deviation (SD) and coefficient of variation (CV) were calculated for sediment samples in Xuwei-Liezikou offshore area. The inverse distance weight method was used to carry out spatial interpolation of heavy metals, and ArcGIS10.2 spatial analysis module was used to draw the spatial distribution figures of heavy metal contents.

\section{Geo-accumulation index $\left(I_{g e o}\right)$}

Geo-accumulation index ( $\left.I_{g e o}\right)$, originally defined by Müller (1969), has been widely used to assess heavy metal pollution in the environment (Wang et al., 2015; Malvandi, 2017; Nethaji et al., 2017; Naifar et al., 2018). The formula used for the calculation of $I_{g e o}$ is as follows:

$$
I_{g e o}=\log _{2} \frac{C_{n}}{1.5 B_{n}}
$$

where $C_{n}$ and $B_{n}$ are the actual measured content of the heavy metal and the natural background value of the heavy metal, respectively. In this study, the background values of heavy metals in coastal soil in Jiangsu Province were used for $B_{n}$ (Chen et al., 1985). Its degree of pollution of Müller (1981) is shown in Table 2.

\section{Pollution load index (PLI)}

Pollution load index $(P L I)$ is an evaluation method proposed by Tomlinson and others in the study of heavy metal pollution level classification (Tomlinson et al., 1980; Badr et al., 2009), and it is convenient to apply. The index is composed of various heavy metal components in the study area. It can reflect the contribution of various heavy metals to pollution and the changing trend of heavy metals in space. The equation is shown as follows:

$$
\begin{gathered}
C_{f}^{i}=C_{n}^{i} / C_{0}^{i} \\
P L I=\sqrt[n]{C_{f}^{1} \times C_{f}^{2} \times C_{f}^{3} \times \cdots \times C_{f}^{n}}
\end{gathered}
$$

where $C_{f}^{i}$ is the pollution coefficient of the heavy metal $i$; $C_{n}{ }^{i}$ is the measured concentration value of heavy metal $i ; C_{0}{ }^{i}$ is the background value for heavy metal $i$. In this study, the natural background values of heavy metals in coastal soil in Jiangsu Province are adopted for $C_{0}{ }^{i}$ (Chen et al., 1985); $n$ is the number of heavy metals; PLI is 
the pollution load index at a certain sample site. The pollution load index is generally divided into 4 grades (Zhu et al., 2013; Maanan et al., 2015), as shown in Table 2.

\section{Potential ecological risk index}

In 1980, Swedish scholar Lars Hakanson proposed a potential ecological risk index method for evaluating heavy metal pollution and ecological risk based on sedimentology principles (Hakanson, 1980). This evaluation method comprehensively considers the toxicity of heavy metals, the difference of background values of heavy metals, the sensitivity of heavy metal pollution under the effect of evaluation areas, and the general rule concerning the migration and transformation of heavy metals in sediments, the calculation equations can be express as follows:

$$
\begin{aligned}
& C_{f}^{i}=C_{n}^{i} / C_{0}^{i} \\
& C_{R I}=\sum_{i}^{n} C_{f}^{i} \\
& E_{r}^{i}=T_{r}^{i} \times C_{f}^{i} \\
& E_{R I}=\sum_{i=1}^{m} E_{r}^{i}
\end{aligned}
$$

where the meanings of $C_{f}^{i}, C_{n}{ }^{i}$ and $C_{0}{ }^{i}$ are the same as in Eq.2; $n$ is the number of heavy metals; $C_{R I}$ is the comprehensive contamination coefficient; $E_{r}{ }^{i}$ is the potential ecological risk index for heavy metal $i ; T_{r}^{i}$ is the heavy metal toxicity response coefficient that reflects the toxicity level of heavy metals and the sensitivity of organisms to heavy metal pollution, the toxicity response coefficient for $\mathrm{As}, \mathrm{Hg}, \mathrm{Cu}, \mathrm{Pb}$, $\mathrm{Zn}, \mathrm{Cd}$ and $\mathrm{Cr}$ are 10, 40, 5, 5, 1, 30 and 2, respectively (Hakanson, 1980); $E_{R I}$ is the comprehensive potential ecological risk index of the heavy metals in the study area. The relationship among the evaluation index of heavy metal pollution, its degree of pollution and the degree of potential ecological risk of Hakanson (1980) are shown in Table 2.

\section{Results and discussion}

\section{Concentration of heavy metals in Xuwei-Liezikou offshore area}

The contents of heavy metals in the surface sediments of Xuwei-Liezikou offshore area are showed in Table 3. The concentrations (mg/kg) of $\mathrm{As}, \mathrm{Hg}, \mathrm{Cu}, \mathrm{Pb}, \mathrm{Zn}, \mathrm{Cd}$ and $\mathrm{Cr}$ were in the ranges of 4.67 17.90, 0.011 0.062, 10.00 32.30, 14.40 33.50, $40.00 \sim 84.70,0.049 \sim 0.211$ and 30.10 74.70, with the averages of 12.54, 0.03, 19.84, 22.31, 66.80, 0.11 and 42.67, respectively. The mean concentrations for these metals were ranked as follows: $\mathrm{Zn}>\mathrm{Cr}>\mathrm{Pb}>\mathrm{Cu}>\mathrm{As}>\mathrm{Cd}>\mathrm{Hg}$. All the heavy metals contents were lower than Class I sediment category according to the Chinese Marine Sediment Quality standard criteria (GB 18668-2002) issued by the Administration of Quality Supervision, Inspection and Quarantine (AQSIQ, 2002), indicating that the sediment environment in the study area was generally good. 
Table 2. Standard for geo-accumulation index, potential ecological risk index and potential ecological risk index of heavy metals

\begin{tabular}{|c|c|c|c|c|c|c|c|c|c|c|c|}
\hline Igeo & Pollution level & PLI & Pollution level & $C_{f}^{i}$ & $\begin{array}{l}\text { Single-factor } \\
\text { pollution level }\end{array}$ & $C_{R I}$ & $\begin{array}{l}\text { Comprehensive } \\
\text { pollution level }\end{array}$ & $\boldsymbol{E}_{r}^{i}$ & $\begin{array}{c}\text { Single-factor } \\
\text { ecological risk } \\
\text { level }\end{array}$ & $E_{R I}$ & $\begin{array}{c}\text { Comprehensive } \\
\text { potential ecological } \\
\text { risk level }\end{array}$ \\
\hline$\leq 0$ & Unpolluted & $<1$ & unpolluted & $<1$ & Low & $<8$ & Low & $<40$ & Low & $<150$ & Low \\
\hline $0 \sim 1$ & $\begin{array}{l}\text { Unpolluted to } \\
\text { moderate }\end{array}$ & $1 \sim 2$ & moderate & $1 \sim 3$ & Moderate & $8 \sim 16$ & Moderate & $40 \sim 80$ & Moderate & $150 \sim 300$ & Moderate \\
\hline $1 \sim 2$ & Moderate & $2 \sim 3$ & strong & $3 \sim 6$ & High & $16 \sim 32$ & Heavy & $80 \sim 160$ & Considerable & $300 \sim 600$ & Considerable \\
\hline $2 \sim 3$ & $\begin{array}{l}\text { Moderate to } \\
\text { strong }\end{array}$ & $\geq 3$ & extreme & $\geq 6$ & Severe & $\geq 32$ & Severe & $160 \sim 320$ & High & $\geq 600$ & Severe \\
\hline $3 \sim 4$ & Strong & & & & & & & $\geq 320$ & Severe & & \\
\hline $4 \sim 5$ & $\begin{array}{l}\text { Strong to } \\
\text { extreme }\end{array}$ & & & & & & & & & & \\
\hline$>5$ & Extreme & & & & & & & & & & \\
\hline
\end{tabular}

Table 3. Descriptive statistic of heavy metal concentrations in surface sediments in Xuwei-Liezikou offshore Area. Comparison of heavy metal concentrations of surface sediments in the study area and other representative areas in China (unit: $\mathrm{mg} / \mathrm{kg}$ )

\begin{tabular}{|c|c|c|c|c|c|c|c|c|c|}
\hline & & As & $\mathbf{H g}$ & $\mathrm{Cu}$ & $\mathbf{P b}$ & $\mathbf{Z n}$ & Cd & $\mathrm{Cr}$ & References \\
\hline \multirow{4}{*}{ Study Area } & Range & $4.67 \sim 17.90$ & $0.011 \sim 0.062$ & $10.00 \sim 32.30$ & $14.40 \sim 33.50$ & $40.00 \sim 84.70$ & $0.049 \sim 0.211$ & $30.10 \sim 74.70$ & \multirow{4}{*}{ This study } \\
\hline & Mean & 12.54 & 0.03 & 19.84 & 22.31 & 66.80 & 0.11 & 42.67 & \\
\hline & SD & 3.523 & 0.013 & 5.200 & 4.994 & 11.342 & 0.042 & 10.357 & \\
\hline & $\mathrm{CV}(\%)$ & 28.10 & 41.89 & 36.21 & 22.39 & 16.98 & 36.54 & 24.27 & \\
\hline \multicolumn{2}{|c|}{ South Jiangsu Province } & na & na & 19.1 & 19.7 & 62.6 & 0.12 & 72.8 & Qiu et al., 2018 \\
\hline \multicolumn{2}{|c|}{ Laizhou Bay } & 7.1 & 0.04 & 10.99 & 13.37 & 50.63 & 0.19 & 32.69 & $\begin{array}{c}\text { Zhang and Gao, } \\
2015\end{array}$ \\
\hline \multirow{2}{*}{\multicolumn{2}{|c|}{$\begin{array}{l}\text { Rizhao offshore area } \\
\text { Guangdong coastal } \\
\text { region }\end{array}$}} & 17.54 & 0.02 & 15.92 & 29.23 & 42.84 & 0.08 & 43.25 & Song et al., 2017 \\
\hline & & 20.83 & 0.13 & 43.83 & 44.29 & 139.93 & 0.38 & 86.97 & Zhao et al., 2016 \\
\hline \multicolumn{2}{|c|}{$\begin{array}{c}\text { CMSQ- I } \\
\text { Background value }\end{array}$} & $\begin{array}{c}20 \\
7.38\end{array}$ & $\begin{array}{c}0.2 \\
0.023 \\
\end{array}$ & $\begin{array}{c}35 \\
15.02 \\
\end{array}$ & $\begin{array}{c}60 \\
11.40 \\
\end{array}$ & $\begin{array}{c}150 \\
47.15 \\
\end{array}$ & $\begin{array}{c}0.5 \\
0.042 \\
\end{array}$ & $\begin{array}{c}80 \\
60.11 \\
\end{array}$ & $\begin{array}{c}\text { AQSIQ, } 2002 \\
\text { Chen et al., } 1985 \\
\end{array}$ \\
\hline
\end{tabular}

CMSQ- I is Class I sediment category of the Chinese Marine Sediment Quality standard criteria (GB 18668-2002) issued by the Administration of Quality Supervision, Inspection and Quarantine (AQSIQ, 2002) 
Compared to the background values of heavy metals in coastal soil in Jiangsu Province (Chen et al., 1985), the mean concentrations of $\mathrm{Cd}, \mathrm{Pb}, \mathrm{As}, \mathrm{Zn}, \mathrm{Cu}$ and $\mathrm{Hg}$ were higher than the background values in the Jiangsu province except for $\mathrm{Cr}$, which were $2.62,1.96,1.70,1.42,1.32$ and 1.30 times of their respective background values, indicating there were obvious accumulations of these heavy metals in surface sediments. The standard deviation (SD) and coefficient of variation (CV) indicated moderate variability for $\mathrm{As}, \mathrm{Pb}, \mathrm{Zn}, \mathrm{Cr}(15 \%<\mathrm{CV}<36 \%)$ and high variability for $\mathrm{Hg}, \mathrm{Cu}, \mathrm{Cd}$ (CV>36\%) according to Phil-Eze (2010). These coefficients of variation of the heavy metals were higher, and the heavy metal concentrations varied over a wide range, which suggested an imbalance in the spatial distribution.

We compared the heavy metal concentrations in the study area with those other representative areas in China are also listed in Table 3. The mean concentrations of all heavy metals in study area were lower than those found in sediments of Guangdong coast. The mean $\mathrm{Cu}$ and $\mathrm{Zn}$ concentrations in study area were higher than those in South Jiangsu Province, Laizhou Bay and Rizhao offshore area. The mean concentrations of $\mathrm{Cd}$ and $\mathrm{Cr}$ in study area were lower than those in South Jiangsu Province. The mean As, $\mathrm{Pb}$ and $\mathrm{Cr}$ concentration was higher in study area than in Laizhou Bay, but lower than in Rizhao offshore area. The mean $\mathrm{Cd}$ and $\mathrm{Hg}$ concentration was higher in study area than in Rizhao offshore area, but lower than in Laizhou Bay.

\section{Spatial distribution of the heavy metal concentrations}

The spatial distributions of heavy metals in surface sediments of Xuwei-Liezikou offshore area are presented in Fig. 2.

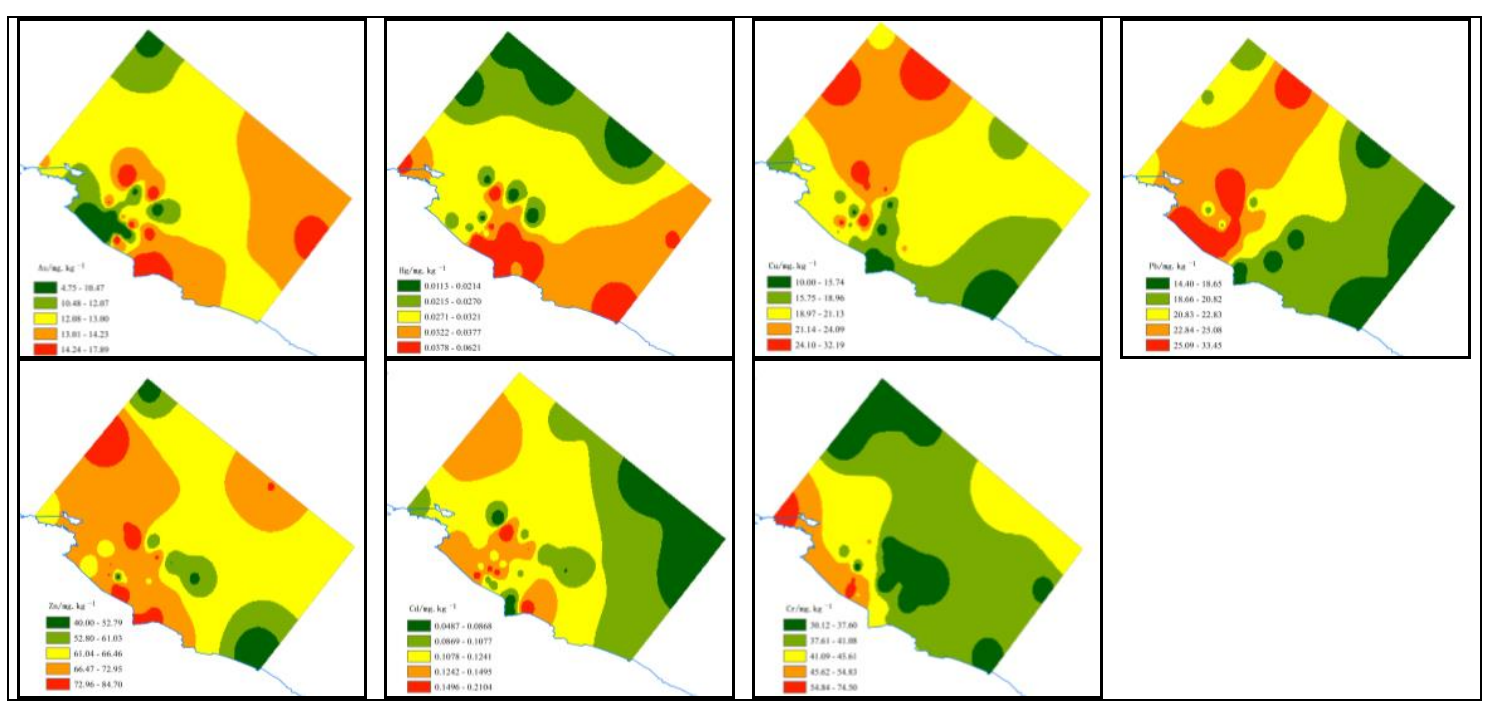

Figure 2. Spatial distribution of heavy metals in Xuwei-Liezikou offshore Area

The spatial distributions of $\mathrm{Zn}, \mathrm{Hg}, \mathrm{Cd}$ and As were similar, these elements had high concentration values in the western region of the study area, which was consistent with the major rivers inlets. The high concentration values of $\mathrm{Pb}$ were in the northern of the study area mainly located in the Xuwei Port. $\mathrm{Cu}$ tended to be higher in the northwest and lower in the southeast. In general, the heavy metal high-values areas, the western and northern region of the study area, were mainly located at the river estuaries and 
Xuwei Port. The result showed that land-based pollutants and ship pollutants had an important influence on heavy metal pollution in the study area.

\section{Assessment of heavy metal contamination}

\section{Geo-accumulation indices of the heavy metals}

The geo-accumulation indices $\left(I_{g e o}\right)$ of the heavy metals in Xuwei-Liezikou offshore area are shown in Table 4. The $I_{g e o}$ values of $\mathrm{As}, \mathrm{Hg}, \mathrm{Cu}, \mathrm{Pb}, \mathrm{Zn}, \mathrm{Cd}$ and $\mathrm{Cr}$ were in the ranges of $-1.25 \sim 0.69,-1.61 \sim 0.85,-1.17 \sim 0.52,-0.25 \sim 0.97,-0.82 \sim 0.26,-0.37 \sim 1.74$ and $-1.58 \sim-0.27$, with the averages of $0.11,-0.26,-0.23,0.35,-0.11,0.76$ and -1.12 , respectively. The mean $I_{\text {geo }}$ values were ranked as follows: $\mathrm{Cd}>\mathrm{Pb}>\mathrm{As}>\mathrm{Zn}>\mathrm{Cu}>\mathrm{Hg}>\mathrm{Cr}$. According to Müller (1981), the mean $I_{g e o}$ values in the study area ranged form -2 to 1 , showing unpolluted and unpolluted to moderate polluted. The result indicated that the study area has not been obviously polluted as a whole. However, the $I_{g e o}$ values of $\mathrm{Cd}$ ranged from -0.37 to 1.74 , and $10 \%$ of the sampling sites were unpolluted, $33 \%$ were unpolluted to moderately polluted, $57 \%$ were moderately polluted. The sampling sites that were moderately polluted for $\mathrm{Cd}$ were mainly distributed in the western region of the study area (Fig. 3a), indicating that the land-based pollutants had an important impact on the sediment environment in the study area. Meanwhile, it should be noted that the $I_{g e o}$ values form $87 \%$ of the sampling sites for $\mathrm{Pb}$ ranged form 0 to 1 , indicating unpolluted to moderately polluted, the high $I_{g e o}$ values were located in the Xuwei port (Fig. 3b). Overall, the surface sediments were a low degree of pollution throughout the study area, and $\mathrm{Cd}$ and $\mathrm{Pb}$ were the main pollution factors.

Table 4. Geo-accumulation indices $\left(I_{\text {geo }}\right)$ and contamination degree of surface sediments

\begin{tabular}{|c|c|c|c|c|c|c|c|}
\hline Igeo & As & Hg & $\mathbf{C u}$ & $\mathbf{P b}$ & $\mathbf{Z n}$ & Cd & $\mathrm{Cr}$ \\
\hline Min & -1.25 & -1.61 & -1.17 & -0.25 & -0.82 & -0.37 & -1.58 \\
\hline Max & 0.69 & 0.85 & 0.52 & 0.97 & 0.26 & 1.74 & -0.27 \\
\hline Mean & 0.11 & -0.26 & -0.23 & 0.35 & -0.11 & 0.76 & -1.12 \\
\hline \multicolumn{8}{|c|}{ Compared with $I_{g e o}$ (\% of sample in each class) } \\
\hline$I_{g e o} \leq 0$ & $30 \%$ & $57 \%$ & $77 \%$ & $13 \%$ & $63 \%$ & $10 \%$ & $100 \%$ \\
\hline $0<I_{\text {geo }} \leq 1$ & $70 \%$ & $43 \%$ & $23 \%$ & $87 \%$ & $37 \%$ & $33 \%$ & $0 \%$ \\
\hline $1<I_{g e o} \leq 2$ & $0 \%$ & $0 \%$ & $0 \%$ & $0 \%$ & $0 \%$ & $57 \%$ & $0 \%$ \\
\hline
\end{tabular}
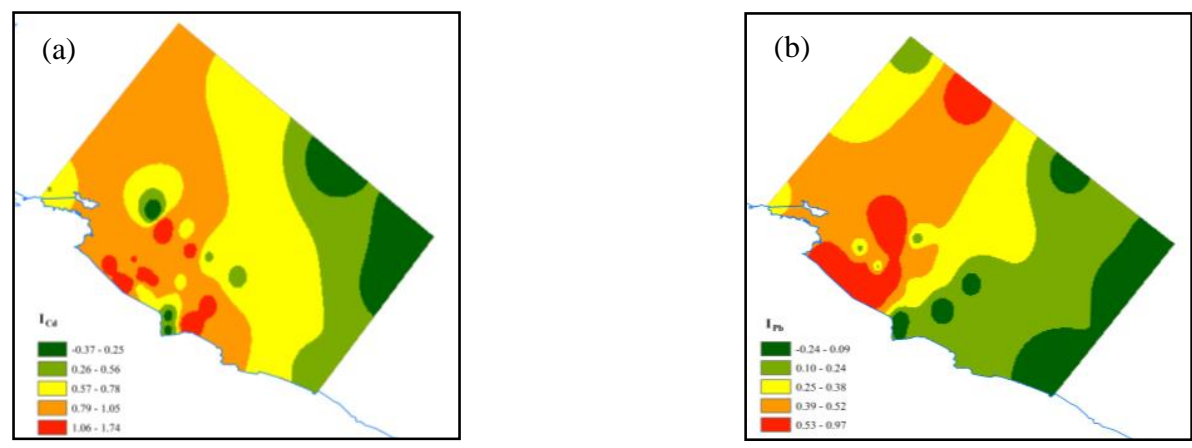

Figure 3. Spatial distribution of the geo-accumulation indices for $\mathrm{Cd}$ and $\mathrm{Pb}$ Pollution load indices of the heavy metals 
The pollution load indices (PLI) of the heavy metals for surface sediments of Xuwei-Liezikou offshore area are presented in Table 5. The PLI values in the study area ranged from 1.15 to 1.91 , with the averages of 1.44 , the Xuwei-Liezikou offshore area was considered to be moderately polluted. $100 \%$ of all sample sites showed moderately polluted, indicating that the study area was affected by human activities. The high PLI values were in the western and northern region of the study area (Fig. 4a). The result was similar to the distribution characteristics of main pollution elements.

Table 5. The pollution load indices of the heavy metals in the study area

\begin{tabular}{cc|cc|cc}
\hline Sample & $\boldsymbol{P L I}$ & Sample & $\boldsymbol{P L I}$ & Sample & $\boldsymbol{P L I}$ \\
\hline 1 & 1.18 & 12 & 1.35 & 23 & 1.61 \\
2 & 1.51 & 13 & 1.15 & 24 & 1.41 \\
3 & 1.55 & 14 & 1.40 & 25 & 1.52 \\
4 & 1.36 & 15 & 1.43 & 26 & 1.49 \\
5 & 1.28 & 16 & 1.27 & 27 & 1.48 \\
6 & 1.84 & 17 & 1.91 & 28 & 1.44 \\
7 & 1.89 & 18 & 1.63 & 29 & 1.40 \\
8 & 1.15 & 19 & 1.18 & 30 & 1.41 \\
9 & 1.28 & 20 & 1.45 & Min & 1.15 \\
10 & 1.54 & 21 & 1.30 & Max & 1.91 \\
11 & 1.31 & 22 & 1.51 & Mean & 1.44 \\
\hline
\end{tabular}
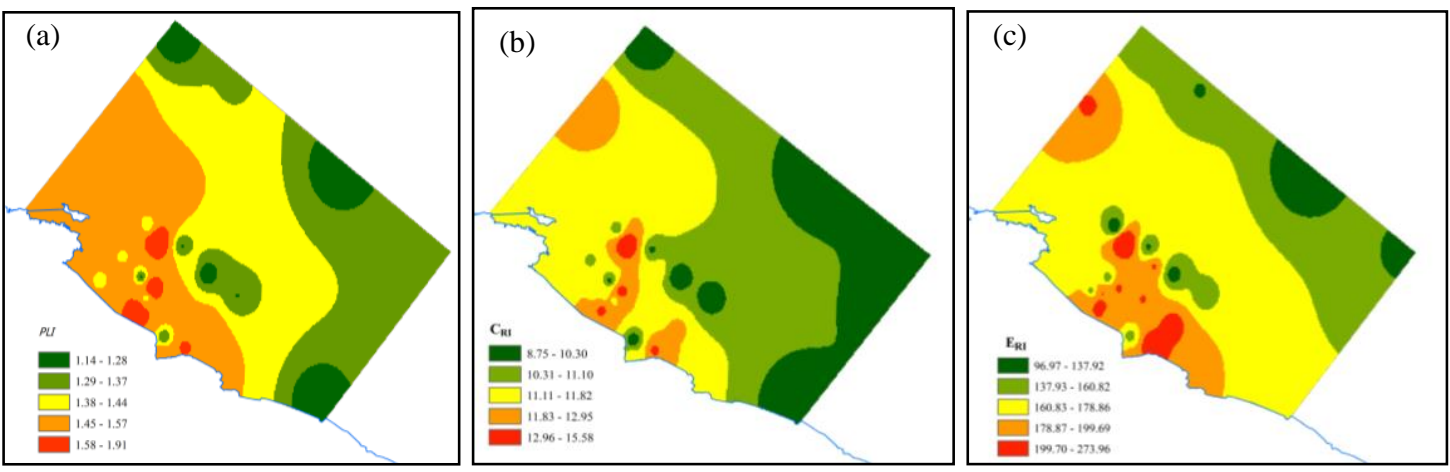

Figure 4. Spatial distribution of PLI, $C_{R I}$ and $E_{R I}$ of heavy metals

\section{Potential ecological risk index in Xuwei-Liezikou offshore area}

The contamination factor $\left(C_{f}^{i}\right)$ values for the heavy metals in Xuwei-Liezikou offshore area are showed in Table 6. The mean $C_{f}^{i}$ values of $\mathrm{As}, \mathrm{Hg}, \mathrm{Cu}, \mathrm{Pb}, \mathrm{Zn}, \mathrm{Cd}$ and $\mathrm{Cr}$ were $1.70,1.30,1.32,1.96,1.42,2.62$ and 0.71 , ranked as follows: $\mathrm{Cd}>\mathrm{Pb}>\mathrm{As}>\mathrm{Zn}>\mathrm{Cu}>\mathrm{Hg}>\mathrm{Cr}$. $67 \%$ of the sampling sites for $\mathrm{Cd}$ were moderate pollution, while $33 \%$ (mainly located in the nearshore region) showed high pollution. $100 \%$ of the sampling sites for $\mathrm{Pb}$ were moderate pollution, and the high $C_{f}^{i}$ values for $\mathrm{Pb}$ located in Xuwei Port. The $C_{f}^{i}$ values of others elements showed low to moderate pollution. The $C_{R I}$ values of the study area ranged from 8.75 to 15.6 , with the mean of 11.21, indicating a moderate pollution. The high $C_{R I}$ value distributed in the western and northern regions of the study area, mainly located in the estuary and port regions (Fig. 4b).

The potential ecological risk indices for the heavy metals in Xuwei-Liezikou offshore area are showed in Table 7 and Fig. 4c. The mean $E_{r}^{i}$ values for $\mathrm{As}, \mathrm{Hg}, \mathrm{Cu}, \mathrm{Pb}$, $\mathrm{Zn}, \mathrm{Cd}$ and $\mathrm{Cr}$ were 17.03, 55.42, 6.60, 9.78, 1.42, 81.78 and 1.42, ranked as 
follows: $\mathrm{Cd}>\mathrm{Hg}>\mathrm{As}>\mathrm{Pb}>\mathrm{Cu}>\mathrm{Cr}=\mathrm{Zn}$. The mean $E_{r}{ }^{i}$ values for $\mathrm{Cd}$ showed a considerable ecological risk, $\mathrm{Hg}$ was a moderate ecological risk, the others elements were a low ecological risk. The $E_{R I}$ values ranged from 96.97 to 274.62 , with an average value of 173.46, which were a low to middle ecological risk (Table 2). The high $E_{R I}$ values distributed in the western region of the study area (Fig. $4 \mathrm{c})$, mainly located in the estuary regions, which was similar to the Cd distribution characteristics (Fig. 2). These results showed that the risks were mainly from $\mathrm{Cd}$.

Table 6. Contamination factor of the heavy metals in surface sediments

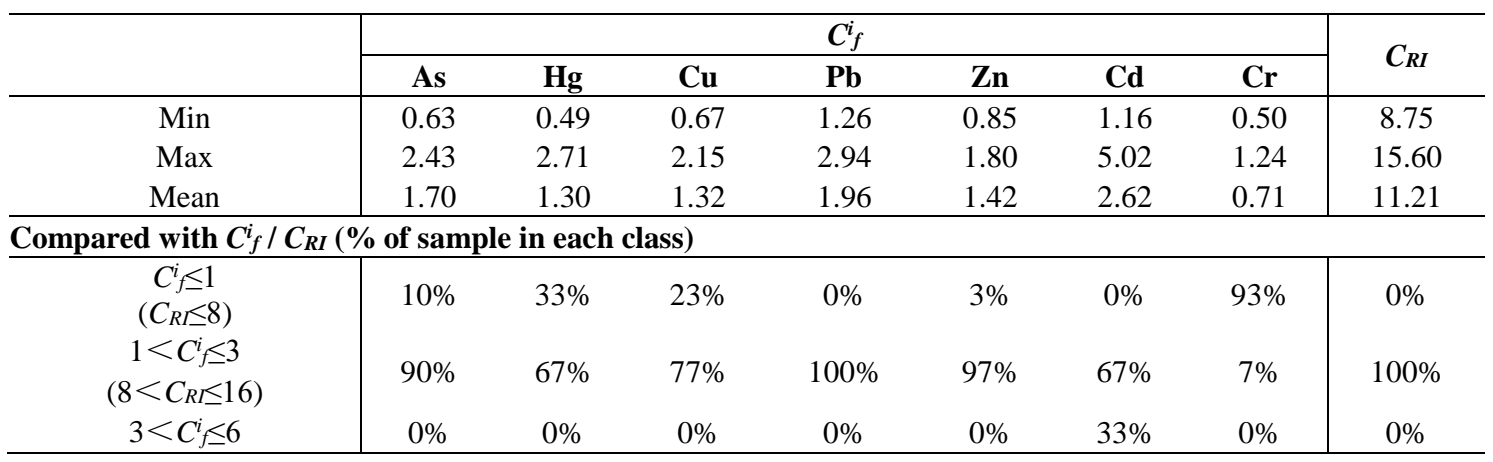

Table 7. Potential ecological risk indices of the heavy metals in surface sediments

\begin{tabular}{c|ccccccc|c}
\hline & \multicolumn{7}{|c|}{$\boldsymbol{E}_{\boldsymbol{r}}{ }^{\boldsymbol{1}}$} & \multirow{2}{*}{$\boldsymbol{E}_{\boldsymbol{R I}}$} \\
\cline { 2 - 7 } & $\mathbf{A s}$ & $\mathbf{H g}$ & $\mathbf{C u}$ & $\mathbf{P b}$ & $\mathbf{Z n}$ & $\mathbf{C d}$ & $\mathbf{C r}$ & \\
\hline Min & 6.33 & 19.65 & 3.33 & 6.32 & 0.85 & 34.71 & 1.00 & 96.97 \\
Max & 24.26 & 108.35 & 10.75 & 14.69 & 1.80 & 150.71 & 2.49 & 274.62 \\
Mean & 17.03 & 55.42 & 6.60 & 9.78 & 1.42 & 81.78 & 1.42 & 173.46 \\
\hline
\end{tabular}

\section{Conclusion}

The mean concentrations (mg/kg) of $\mathrm{As}, \mathrm{Hg}, \mathrm{Cu}, \mathrm{Pb}, \mathrm{Zn}, \mathrm{Cd}$ and $\mathrm{Cr}$ were $12.54,0.03$, 19.84, 22.31, 66.80, 0.11and 42.67 in surface sediments of Xuwei-Liezikou offshore area, respectively. The averages of $\mathrm{Cd}, \mathrm{Pb}, \mathrm{As}, \mathrm{Zn}, \mathrm{Cu}$ and $\mathrm{Hg}$ were higher than the background values in the Jiangsu province except for $\mathrm{Cr}$, which were 2.62, 1.96, 1.70, $1.42,1.32$ and 1.30 times of their respective background values, indicating there were obvious accumulations of these heavy metals of the study area. The spatial distributions of heavy metals showed that $\mathrm{Zn}, \mathrm{Hg}, \mathrm{Cd}$ and $\mathrm{As} \mathrm{had} \mathrm{high} \mathrm{concentration} \mathrm{values} \mathrm{in} \mathrm{the}$ western region of the study area, which was consistent with the rivers inlets, and the high concentration values of $\mathrm{Pb}$ were in the northern of the study area mainly located in the Xuwei Port. The results of contamination assessment showed the study area was moderately polluted, and the main pollution areas were in the western and northern region. The pollution mainly came form $\mathrm{Cd}$ and $\mathrm{Pb}$. For the main pollution factors, further studies on their sources and impacts can be conducted to provide data for environmental protection. The study area suffered from a level between low and moderate risks, and $\mathrm{Cd}$ was an important factor causing ecological risks. The estuary areas where were prone to ecological risk should be paid attention to. 


\section{REFERENCES}

[1] AQSIQ (Administration of Quality Supervision, Inspection and Quarantine of the People's Republic of China) (2002): Marine Sediment Quality of China (GB 18668-2002). - Standards Press of China, Beijing.

[2] AQSIQ (Administration of Quality Supervision, Inspection and Quarantine of the People's Republic of China) (2007): Marine Monitoring Regulations of China (GB 17378-2007). - Standards Press of China, Beijing.

[3] Badr, N. B. E., El-Fiky, A. A., Mostafa, A. R., Al-Mur, B. A. (2009): Metal pollution records in core sediments of some Red Sea coastal areas, Kingdom of Saudi Arabia. Environmental Monitoring \& Assessment 155(1-4): 509-526.

[4] Bastami, K. D., Neyestani, M. R., Shemirani, F., Soltani, F., Haghparast, S., Akbari, A. (2015): Heavy metal pollution assessment in relation to sediment properties in the coastal sediments of the southern Caspian Sea. - Marine Pollution Bulletin 92(1-2): 237-243.

[5] Burger, J., Gochfeld, M. (2003): Spatial and temporal patterns in metal levels in eggs of common terns (Sterna hirundo) in New Jersey. - Science of the Total Environment 311(1): 91-100.

[6] Chen, B. B., Hu, R. Q., Chen, M. D. (1985): Natural background values of environmental elements in coastal soil in Jiangsu. - Journal of Nanjing Agricultural University 8(3): 54-60.

[7] Chen, M., Ding, S., Zhang, L., Li, Y., Sun, Q., Zhang, C. (2017): An investigation of the effects of elevated phosphorus in water on the release of heavy metals in sediments at a high resolution. - Science of the Total Environment 575: 330-337.

[8] Fang, H. W., Huang, L., Wang, J. Y., He, G. J., Reible, D. (2016): Environmental assessment of heavy metal transport and transformation in the Hangzhou Bay, China. Hazard Mater 302: 447-457.

[9] Gao, X., Zhou, F., Chen, C. A., Xing, Q. (2015): Trace metals in the suspended particulate matter of the Yellow River (Huanghe) estuary: concentrations, potential mobility, contamination assessment and the fluxes into the Bohai Sea. - Continental Shelf Research 104: 25-36.

[10] Hakanson, L. (1980): An ecological risk index for aquatic pollution control: a sediment ecological approach. - Water Research 14(8): 975-1001.

[11] Harikrishnan, N., Ravisankar, R., Chandrasekaran, A. (2017): Assessment of heavy metal contamination in marine sediments of East Coast of Tamil Nadu affected by different pollution sources. - Marine Pollution Bulletin 121: 418-424.

[12] Hill, N. A., Simpson, S. L., Johnston, E. L. (2013): Beyond the bed: effects of metal contamination on recruitment to bedded sediments and overlying substrata. Environmental Pollution 173: 182-191.

[13] Hu, G., Yu, R., Zhao, J., Chen, L. (2011): Distribution and enrichment of acid-leachable heavy metals in the intertidal sediments from Quanzhou Bay, southeast coast of China. Environmental Monitoring \& Assessment 173(1-4): 107-116.

[14] Irabien, M. J., Velasco, F. (1999): Heavy metals in Oka River sediments (Urdaihai National Biosphere Reserve, Northern Spain): Lithogenic and anthropogenic effects. Environmental Geology 37(1-2): 54-63.

[15] Li, Y., Li, H. G. (2016): Historical records of trace metals in core sediments from the Lianyungang coastal sea, Jiangsu, China. - Marine Pollution Bulletin 116: 56-63.

[16] Maanan, M. M., Saddik, M., Chaibi, M., Assobhei, O., Zourarah, B. (2015): Environmental and ecological risk assessment of heavy metals in sediments of Nador lagoon, Morocco. - Ecological Indicators 48: 616-626.

[17] Machado, A. A. D. S., Spencer, K., Kloas, W., Toffolon, M., Zarfl, C. (2016): Metal fate and effects in estuaries: a review and conceptual model for better understanding of toxicity. - Science of the Total Environment 541: 268-281. 
[18] Malvandi, H. (2017): Preliminary evaluation of heavy metal contamination in the Zarrin-Gol River sediments, Iran. - Marine Pollution Bulletin 117(1-2): 547-553.

[19] Matthiessen, P., Law, R. J. (2002): Contaminants and their effects on estuarine and coastal organisms in the United Kingdom in the late twentieth century. - Environmental Pollution 120(3): 739-757.

[20] Müller, G. (1969): Index of geoaccumulation in sediments of the Rhine River. Geojournal 2(3): 108-118.

[21] Müller, G. (1981): Die Schwermetallbelastung der sedimente des Neckars und seiner Nebenflusse: eine Bestandsaufnahme. - Chemiker Zeitung 105: 157-164.

[22] Naifar, I., Pereira, F., Zmemla, R. (2018): Spatial distribution and contamination assessment of heavy metals in marine sediments of the southern coast of Sfax, Gabes Gulf, Tunisia. - Marine Pollution Bulletin 131: 53-62.

[23] Nethaji, S., Kalaivanan, R., Viswam, A. (2017): Geochemical assessment of heavy metals pollution in surface sediments of Vellar and Coleroon estuaries, southeast coast of India. - Marine Pollution Bulletin 115(1-2): 469.

[24] Phil-Eze, P. O. (2010): Variability of soil properties related to vegetation cover in a tropical rainforest landscape. - Journal of Geography and Regional Planning 3(7): 177-184.

[25] Qiu, J. D., Liu, J. Q., Li, M. N., Wang, S., Bai, W. M., Zhang, D. L. (2018): Assessment of heavy metal contamination in surface sediments from the nearshore zone, southern Jiangsu Province, China. - Marine Pollution Bulletin 133: 281-288.

[26] Song, H., Liu, J., Yin, P. (2017): Distribution, enrichment and source of heavy metals in Rizhao offshore area, southeast Shandong Province. - Marine Pollution Bulletin 119: 175-180.

[27] Tomlinson, D. C., Wilson, J. G., Harris, C. R., Jeffery, D. W. (1980): Problems in the assessment of heavy-metal levels in estuaries and the formation of a pollution index. Helgoländer Meeresuntersuchungen 33(1-4): 566-575.

[28] Waheed, S., Malik, R. N., Jahan, S. (2013): Health risk from As contaminated fish consumption by population living around River Chenab, Pakistan. - Environmental Toxicology \& Pharmacology 36(2): 579-587.

[29] Wang, H., Wang, J., Liu, R., Yu, W., Shen, Z. (2015): Spatial variation, environmental risk and biological hazard assessment of heavy metals in surface sediments of the yangtze river estuary. - Marine Pollution Bulletin 93(1-2): 250-258.

[30] Zhang, J., Gao, X. (2015): Heavy metals in surface sediments of the intertidal Laizhou Bay, Bohai Sea, China: Distributions, sources and contamination assessment. - Marine Pollution Bulletin 98: 320-327.

[31] Zhang, R., Zhou, L., Zhang, F., Ding, Y. J., Gao, J. R., Chen, J., Yan, H. Q. (2013): Heavy metal pollution and assessment in the tidal flat sediments of Haizhou Bay, China. - Marine Pollution Bulletin 74: 403-412.

[32] Zhang, R., Guan, M. L., Shu, Y. J., Shen, L. Y., Chen, X. X., Zhang, F., Li, T. G. (2016): Historical record of lead accumulation and source in the tidal flat of Haizhou Bay, Yellow Sea: Insights from lead isotopes. - Marine Pollution Bulletin 106: 383-387.

[33] Zhang, P., Hu, R. J., Zhu, L. H., Wang, P., Yin, D. X., Zhang, L. J. (2017): Distributions and contamination assessment of heavy metals in the surface sediments of western Laizhou Bay: Implications for the sources and influencing factors. - Marine Pollution Bulletin 119: 429-438.

[34] Zhao, G., Lu, Q., Ye, S., Yuan, H., Ding, X., Wang, J. (2016): Assessment of heavy metal contamination in surface sediments of the west Guangdong coastal region, China. Marine Pollution Bulletin 108(1-2): 268-274.

[35] Zhu, Z. M., Li, Z. G., Bi, X. Y., Han, Z. X., Yu, G. H. (2013): Response of magnetic properties to heavy metal pollution in dust from three industrial cities in China. - Journal of Hazardous Materials 246-247: 189-198. 